\author{
Ewa Jasiuk
}

Lazarski University, Poland

ORCID: 0000-0002-0918-7225

e.jasiuk@wp.pl

\title{
Preparatory Hearing in the Light of the Amendment to the Civil Procedure Code of 4 July 2019
}

\author{
Posiedzenie przygotowawcze w świetle nowelizacji Kodeksu \\ postępowania cywilnego z dnia 4 lipca 2019 r.
}

\begin{abstract}
This article is a scientific and research study, which includes an analysis of new legal regulations regarding a preparatory hearing in civil proceedings in the light of the amendment to the Civil Procedure Code of 4 July 2019. This article aims to discuss the institution of the preparatory hearing and to attempt to answer the questions whether the adopted shape of the regulation may contribute to increasing the efficiency of civil proceedings and why this institution is rarely used in practice. In addition to presenting the legal regulations concerning the institution of the preparatory hearing, some considerations concerning the practical significance of individual regulations and their impact on the course of civil proceedings were also presented, as well as why these regulations are still rarely used in practice. The article deals with national issues, particularly important for law practitioners.
\end{abstract}

Keywords: civil proceedings; preparatory hearing; efficiency of civil proceedings; Civil Procedure Code; amendment

\section{INTRODUCTION}

This article is a scientific and research study, which includes an analysis of new legal regulations regarding a preparatory hearing in civil proceedings in the light of the amendment to the Civil Procedure Code of 4 July 2019. The purpose is to discuss the institution of the preparatory hearing and to try to answer the questions

CORRESPONDENCE ADDRESS: Ewa Jasiuk, PhD, Assistant Professor, Vice-Dean for Education Quality, Lazarski University (Warsaw), Faculty of Law and Administration, Świeradowska 43, 02-662 Warszawa, Poland. 
whether the adopted shape of the regulation may contribute to the increase in the efficiency of civil proceedings and why is this institution rarely used in practice.

A hypothesis can be made that the adopted shape of the regulations concerning preparatory proceedings may contribute to increasing the efficiency of civil proceedings.

In order to verify the hypothesis, the author analyzed the content, first of all, of the Civil Procedure Code, which required the use of a linguistic and logical method in relation to some basic concepts. It also assumed that it would also be necessary to use the dogmatic and legal method, which was to serve as a thorough analysis of the currently binding legal regulations relevant from the point of view of the discussed subject matter.

In addition to presenting the legal regulations concerning the institution of the preparatory hearing, some considerations concerning the practical significance of individual regulations and their impact on the course of civil proceedings were also presented, as well as why these regulations are still rarely used in practice.

The article deals with national issues, particularly important for law practitioners. Legal literature does not sufficiently focus its attention on the issues outlined in the title. Therefore, there is a need for a more complete approach to the preparatory hearing.

\section{RESEARCH AND RESULTS}

\section{Introductory remarks}

The civil procedure by the Act of 4 July $2019^{1}$ introduced many changes, the main purpose of which is to expedite the proceedings and to persuade the parties to proceed to amicable settlement of the dispute. Many regulations, despite the fact that the above Act largely entered into force on 6 November 2019, are not yet being applied in practice. With each month, however, the number of cases initiated after 6 November 2019 is increasing, which will probably result in the fact that preparatory hearings will be appointed more and more frequently. This will give the opportunity to fully benefit from the provisions introduced in Chapter 2A entitled "Organization of proceedings" (Articles $205^{1}$ to $205^{12}$ - these provisions are included in Part One of the Civil Procedure Code, Book One, Title VI, Section II). Act amending the Civil Procedure Code and certain other acts in Article 17

1 Act 4 July 2019 amending the Act - Code of Civil Procedure and certain other acts (Journal of Laws 2019, item 1469). 
provided for different deadlines for the entry into force of the amended provisions, ${ }^{2}$ but the rule provided for is the direct application of the new provisions to pending cases - Article 9 (2) of the Act of 4 July 2019.

One of these changes, which the legislator intends to expedite the end of the case, are provisions introducing an institution of a preparatory hearing unknown to the Polish civil procedure, as a special stage of the process. Regulations in this respect are included in Articles $205^{4}$ to $205^{11}$ of the Civil Procedure Code. Before the discussed amendment, the doctrine used the concept of preparatory proceedings and preparation of the trial. ${ }^{3}$

The aim of this article is to discuss the institution of the preparatory hearing and to attempt to answer the question whether the adopted shape of the regulation may contribute to increasing the efficiency of civil proceedings and why this institution is rarely used in practice.

Appointing a preparatory hearing is done by the chairman and not by the court. It should also be noted that appointing the preparatory hearing is not obligatory. As stated in Article $205^{4} \S 3$ of the Civil Procedure Code, if the circumstances of the case indicate that conducting a preparatory hearing will not contribute to a more efficient examination of the case, the chairman may give it another appropriate course, in particular refer it to be examined, also at the hearing. According to J. Bodio, it can be pointed out that in cases of simple facts, a small number of reported evidence, or if, according to the chairman's assessment, it is possible to hear the case at one hearing, there is no point in setting a preparatory hearing. ${ }^{4}$

However, if the circumstances of the case do not indicate the above, then the chairman appoints a preparatory hearing and summons the parties. According to the content of Article $205^{4} \S 1$ of the Civil Procedure Code, a preparatory hearing may not be appointed when a default judgement has been delivered.

\section{Response to the lawsuit}

As for the moment of designating the preparatory hearing by the chairman, it cannot be earlier than the day on which the defendant submitted a response to the statement of claim or on which the deadline for submitting this answer has expired ineffectively. In order to properly plan the proceedings (hearing), the court must

2 Cf. Kodeks postępowania cywilnego. Komentarz do ustawy z 4.7.2019 r. o zmianie ustawy - Kodeks postępowania cywilnego oraz niektórych innych ustaw, eds. J. Gołaczyński, D. Szostek, Legalis 2019.

3 More broadly on the legal status before the amendment of 4 July 2019, see J. Bodio, Przygotowanie sprawy do rozpoznania - pisma i postepowanie przygotowawcze, [in:] Nowelizacja Kodeksu postępowania cywilnego z 4.7.2019 r. w praktyce, eds. K. Flaga-Gieruszyńska, R. Flejszar, M. Malczyk, Warszawa 2020, pp. 30-33.

4 Ibidem, p. 43. 
know the demands, statements about the facts and evidence conclusions from both parties. $^{5}$

Until the amendment entered into force on 6 November 2019, such an obligation (to submit a response to the lawsuit) was not always imposed on the defendant. Currently, however, the content of Article $205^{1} \S 1$ of the Civil Procedure Code indicates that the presiding judge shall deliver a copy of the claim to the defendant and summon him to submit a response to the claim, setting a deadline for submitting the response, which cannot be shorter than two weeks. The deadline for submitting a statement of defense is not a statutory deadline, but the so-called court term. This means that it is possible to extend it at the request of a party, if such a request is found to be justified in the opinion of the chairman. The basis for extension of the deadline, in accordance with Article 166 of the Civil Procedure Code, is the occurrence of an important reason. Statutory time limits, provided for by a provision and specifically by a fixed length provision, are not subject to extension.

It should be noted that a very serious consequence of not complying with the time limit for filing a response to a claim is the return of this letter (Article $205^{1} \S 2$ of the Civil Procedure Code). However, a further effect may be the application of Article $339 \S 1$ of the Civil Procedure Code, namely issuing a default judgement in closed session. Pursuant to the provision as mentioned above, the court may issue a default judgement in closed session when the defendant failed to submit a response to the claim within the prescribed period.

However, the court is not obliged to use this provision, and in the situations referred to in Article $339 \S 2$ of the Civil Procedure Code, it is not possible to issue a default judgement without taking evidence. These are situations where the claimant's factual statements raise reasonable doubts or were made to circumvent the law. In such a situation, after the taking of evidence, it is still possible to issue a default judgement if the defendant is still passive.

The instructional period, which concerns the period during which the preparatory hearing is to be scheduled, is 2 months. The beginning of this period is the day on which the response to the claim is lodged, or the deadline for submitting this letter is unsuccessful._However, if the chairman orders an exchange of further preparatory letters, the beginning of the time limit shall be the day on which the last letter was filed or the day on which submitting the letter was ineffective.

\section{Objectives of the preparatory hearing}

There are two objectives of appointing a preparatory hearing arising directly from the content of Article $205^{5} \S 1$ of the Civil Procedure Code. The first is to resolve the dispute without the need for further hearings, and thus simply end the

\footnotetext{
5 Ibidem, p. 35.
} 
case. The second goal that can be achieved when it was not possible to end the case is to prepare a hearing plan with the parties, organizing it so that the examination of the case is efficient and it is clear to the parties when and what proceedings will be performed, but also when the sentence is passed. It seems that reality can quite often and significantly affect the planned date of termination of the case (e.g., lack of attendance of witnesses due to their illness or other justified circumstances, judge's illness, false information about placing a bomb in the court building, technical failures making it impossible to conduct the trial, effective submission of new evidence applications, prolonged period of preparation of an opinion, preparation of an opinion that will be effectively questioned, which will result in the need to admit supplementary opinions or to order another expert's opinion, lack of timely sending of information or case files by another authority, etc.). Therefore, it was rightly noticed in the literature that this optional element of the plan will not be at all implemented in practice.

The preparatory meet hearing is primarily a time when the parties specify their claims, allegations, and motions. The preparatory hearing is, as a rule, to take place in accordance with the provisions on closed session (Article $205^{5} \S 2$ of the Civil Procedure Code). According to Article $205^{5} \S 2$ sentence 2 of the Civil Procedure Code in the course of a preparatory hearing, it is not necessary to comply with detailed procedural provisions, if it contributes to the achievement of the objectives of that hearing, this is left to the discretion of the chairman.

Therefore, the activities undertaken may be informal to some extent, and should take place outside the courtroom as far as possible. ${ }^{6}$ This indication will probably prove impossible in practice in many cases, because in court buildings, apart from courtrooms, suitable places which could accommodate several or a dozen people are usually unavailable. The judge's office, quite often shared with another judge, does not always have a sufficient number of seats, often located in the restricted court building, may not always be used for a preparatory hearing.

After the regulations entered into force, there were voices that during the preparatory hearing, representatives and chairmen may appear without official uniforms (gowns), but the existing legal regulations concerning this have not been changed to this day. Article 7 (2) of the Bar Law and Article 12 (2) of the Act on Counselors in legal terms, concerns the official dress of advocates and legal advisers participating in court hearings while Article 84 (1) of the Act on the System of Common Courts uses a different formulation. Pursuant to this regulation, a judge at a hearing and session with the participation of the parties, held in the court building, wears official clothes. The official dress of a judge is a gown, and as for

${ }^{6}$ Justification of the draft act amending the Act - Civil Procedure Code and certain other acts, Print no. 3137, https://orka.sejm.gov.pl/Druki8ka.nsf/0/166CCC44490F3965C1258384003CD40A/\%24File/3137-uzas.pdf [access: 10.11.2021], p. 11. 
the presiding judge at a trial or session - a chain with an image of an eagle on the collar of the toga is also worn. Only if the underage judge takes part in a hearing, he may refrain from using the official outfit. The preparatory hearing is after all a hearing with the presence of the parties, so it seems that without changing the content of Article 84 (1) of the Act on the System of Common Courts, there is no legal basis for the chairman not to wear a gown.

\section{The inactivity of the party and its consequences}

The legislator predicted very serious consequences when the plaintiff does not appear at the preparatory hearing without justification. As a result of what the legal basis is Article $205^{5} \S 5$ of the Civil Procedure Code is discontinuance of proceedings. At the preparatory hearing, the chairman determines the subject of the dispute with the parties, explains the positions of the parties, also in the part concerning the legal aspects of the dispute (Article $205^{6} \S 1$ of the Civil Procedure Code). For this reason, as indicated in the explanatory memorandum to the draft act, their appearance at the preparatory hearing is to be obligatory, however, depending on the need, the parties may be obligated to appear with proxies or the proxies themselves (Article $205^{5} \S 3$ of the Civil Procedure Code). ${ }^{7}$ The duty of the professional representative is also to warn the party that they may be summoned to appear in person at a preparatory hearing, to inform them of the procedural consequences of failing to appear or not participating in this hearing (Article $205^{5} \S \S 4,5,6$ and 7 of the Civil Procedure Code, Article $103 \S 3$ of the Civil Procedure Code) and preparing it for participation. ${ }^{8}$

The proceedings may not be discontinued despite the fact that the plaintiff or his representative did not appear for the preparatory hearing, if a request was made by the claimant before the preparatory hearing for conducting the preparatory hearing without their participation. Such a request may already be filed by the plaintiff in the lawsuit. It should be clarified that such a request by the claimant does not deprive them of the possibility of appearing in the preparatory hearing. The submission of the above-mentioned application may refer to both the party's absence and the attorney's absence.

The proceedings cannot be discontinued even if the defendant is present at the preparatory hearing objects (Article $205^{5} \S 5$ of the Civil Procedure Code). The defendant, being convinced of the lack of grounds for bringing an action, may be interested in making it impossible in the future to formally effectively re-initiate proceedings in order to pursue the same claim. The severity of the res judicata is

7 Ibidem, p. 13.

8 A. Tomaszek, Nowe powinności adwokackie po nowelizacji procedury cywilnej, "Palestra" 2019, no. 11-12, p. 45. 
a negative procedural premise and causes the need to reject the claim by the court (Article $199 \S 1$ (2) of the Civil Procedure Code).

Discontinuation of the proceedings does not create a res judicata. Such a state arises when a judgement dismissing the claim is passed. When the claimant withdraws the claim and waives the claim at the same time, then we are not dealing with the severity of the res judicata, but simply with the lack of a claim resulting from the waiver of the claim by the given entity. In such a situation, any further claim will be dismissed as unfounded due to the lack of a claim on the plaintiff's side.

The provision as mentioned above provides that the plaintiff has the right, within one week from the date of delivery of the decision to discontinue the proceedings, to justify his non-appearance, then the court repeals the decision to discontinue the proceedings and gives the case the right course. This provision shall not apply in the event of another unexcused non-appearance.

This regulation should be positively assessed, because in life there are sometimes emergency situations that make it impossible to inform the court in due time about the absence, e.g. an accident in which a party will suffer on the way to a hearing. It is also possible to apply for the reinstatement of the deadline for justifying failure to appear, which will be possible, for example, when a party driving to a hearing suffers a road accident, goes to hospital in an unconscious state and will stay there for a long time. Then, within 7 days of the cessation of the cause preventing excuse of absence, a request to restore the deadline can be submitted, subject to the requirements set out in Articles 168-172 of the Civil Procedure Code.

Pursuant to Article $103 \S 3$ of the Civil Procedure Code, if a party, despite being summoned to appear in person, did not appear to participate in court activities and did not justify its failure, the court may, irrespective of the outcome of the case, impose on that party the obligation to reimburse costs in a higher part than the result of the case would require, or even a full refund. In terms of the preparatory hearing, this provision applies to the defendant, because of unexcused absence of the plaintiff. According to Article $205^{5} \S 5$ of the Civil Procedure Code it results in the discontinuation of the proceedings.

As a rule, however, the parties and their proxies are required to attend the preparatory hearing (Article $203^{5} \S 3$ of the Civil Procedure Code). This provision also states that the chairman may release a party from the obligation to attend a preparatory hearing if the circumstances of the case indicate that the attorney's participation will be sufficient. Certainly, such situations will arise especially if the party is a bank or other large institution, where the person or persons leading the institution do not have any specific knowledge about the subject matter. As an example, one can indicate a case concerning the performance of a credit agreement for a small amount, contracted at a bank, where the president of that bank did not participate in the conclusion of this agreement in any way, due to the multitude of such agreements, he was not involved in any specific issues regarding this agree- 
ment. In such a situation it will be obvious that the participation of the representative of this bank will be sufficient.

The party and its representative's failure to appear at the preparatory hearing means that the hearing plan will be prepared without their participation. The same applies if the party appears at the hearing but does not participate (Article $205^{5} \S 7$ of the Civil Procedure Code). However, this party is bound in the course of further proceedings by the findings of the hearing plan made in her absence. The party must also consider the effects of evidence preclusion.

Lack of appearance of the party and its representative at the preparatory session means that the plan of the hearing will be prepared without their participation, of course, subject to the situations discussed above, and regarding the discontinuation of the proceedings pursuant to Article $205^{5} \S 5$ of the Civil Procedure Code. The same applies to situations where a party does appear at the hearing but does not participate in it (Article $205^{5} \S 7$ of the Civil Procedure Code). However, this party is bound in the course of further proceedings with the arrangements of the plan of the hearing made in her absence or at a preparatory hearing, at which she did appear, but did not participate in it. Similar consequences should apply when both parties appear at the preparatory hearing, but their participation is passive. ${ }^{9}$ However, the implications of evidence exclusion should be borne in mind.

Generally speaking, evidence preclusion means that evidence applications may not be taken into account due to the fact that they were submitted too late. It is necessary to distinguish an evidence preclusion from the discretionary power of a judge, however, due to the subject and framework of this study, this issue will not be elaborated on. Evidence preclusion under Article $205^{12} \S 1$ sentence 2 of the Civil Procedure Code, is related to preparatory hearing, and more specifically to its result, and thus the approval of the plan of the hearing. This provision states that the assertions and evidence submitted after the approval of the hearing plan are subject to omission, unless the party lends credence it was not possible to invoke them or the need to invoke them arose later.

However, it should be remembered that the above principles will not apply when pursuant to Article $205^{3} \S 2$ of the Civil Procedure Code, even before the preparatory hearing, the chairman will oblige the party to provide in the preparatory letter all assertions and evidence relevant for the resolution of the case under pain of loss of the right to invoke them in the course of further proceedings. Then, due to the explicit content of Article $205^{3} \S 3$ of the Civil Procedure Code, the appointment of a preparatory hearing will not re-open the deadline for submitting new assertions and evidence.

9 M. Białecki, [in:] Kodeks postępowania cywilnego. Komentarz do zmian 2019. Koszty sadowe w sprawach cywilnych. Dochodzenie roszczeń w postępowaniu grupowym. Przepisy przejściowe, ed. T. Zembrzuski, vol. 1, Legalis 2019, commentary on Article $205^{8}$, notes no. 4 and 5. 
The issue becomes more complicated when at the preparatory hearing circumstances that justify the need to invoke new assertions and evidence arise. Then it will depend on the chairman's assessment ${ }^{10}$ whether the assertions and evidence are omitted as being late or whether they will be included in the hearing plan, due to the recognition that the need to invoke new assertions and evidence arose later, or it was not possible to invoke them earlier.

The need to invoke new assertions and evidence may arise when during a preparatory hearing, as a result of the chairman's implementation of Article $205^{6} \S 1$ of the Civil Procedure Code, ${ }^{11}$ the statement of the opposing party, which did not clearly result from its statement contained in the previously submitted letter (from the claim, from the reply to the claim or from a further preparatory letter). The need to invoke new assertions and evidence may also be a consequence of effective invoking new assertions and evidence by the opposing party.

In practice, problems will probably arise from the fact that in most cases the parties do not use professional legal assistance from the beginning of the proceedings. Therefore, they will not often be able to properly raise all necessary assertions and report all necessary evidence to prove their case and meet the obligation arising from Article 6 of the Civil Code, which stipulates that the burden of proving a fact lies with the person who derives legal effects from this fact.

The possible appearance of a professional representative at a later stage of the proceedings (after approval of the hearing plan) will often give rise to the necessity of difficult to implement attempts to introduce new evidence and to raise new assertions, which the party not being properly prepared, has not submitted so far.

The practice of applying the once binding provisions of separate proceedings in business cases showed that a significant part of the parties' procedural activity was absorbed in demonstrating that the assertions and evidence submitted in the course of the proceedings were not late, or that they merely specify the assertions and evidence previously submitted and thus they are not precluded.

Problems related to this were pointed out at the time, ${ }^{12}$ but they may again gain relevance under the new regulations, if they are very strictly understood by the presidents conducting the preparatory hearing and the courts in the course of further proceedings.

The administration of justice is such a consideration of a case that the Court of Justice has received, so that as a result of the proceedings a fair sentence has been

${ }^{10}$ See T. Guzik, Economic Justification of Judicial Discretion, "Studia Iuridica Lublinensia" 2020, vol. 29(3), pp. 87-97.

${ }^{11}$ Kodeks postepowania cywilnego. Komentarz, vol. 1: Artykuty 1-505 $5^{39}$, ed. T. Szanciło, Legalis 2019, commentary on Article $205^{6}$, note no. 6 .

${ }_{12}$ E. Jasiuk, Konstytucyjne prawo do sąu a pozycja prawno-procesowa przedsiębiorcy $w$ odrębnym postępowaniu w sprawach gospodarczych oraz w świetle ostatnich zmian w Kodeksie postępowania cywilnego, "Rocznik WSH w Radomiu" 2006, vol. 3(1), pp. 53-66. 
passed, and that the actual state of affairs has been established. All this should also be taken into account by the chairman during the preparatory hearing and exercising the right resulting from the content of Article $156^{1}$ of the Civil Procedure Code. Due to the content of Article 3 of the Civil Procedure Code, the parties and participants of the proceedings are also obliged to perform procedural actions in accordance with good practice, provide truthful explanations as to the circumstances of the case and without concealing anything, and present evidence. On the other hand, under Article 232 sentence 2 of the Civil Procedure Code the judge is entitled to admit evidence not indicated by a party, but this should take place exceptionally, ${ }_{13}^{13}$ as the ex officio action of the court may lead to violation of the right to an impartial court and the corresponding obligation to observe the principle of equal treatment of the parties (Article 32 (1) and Article 45 (1) of the Polish Constitution). ${ }^{14}$

It seems that the provisions applicable to the implementation of the amendment in question, namely Article $207 \S 6$ and Article $217 \S 2$ of the Civil Procedure Code, should also result in similar consequences, however, in judicial practice, the rigor of applying these provisions will be very different. From a very liberal approach, especially in labour matters, to much more rigorous in economic matters. The practice in this respect was different in different courts, there was a noticeable tendency to a more rigorous understanding of these provisions in courts with higher case density, and thus usually in courts located in large cities.

\section{Amicable settlement of the case and the role of the chairman in this respect}

The second of the aforementioned objective of the preparatory hearing, namely, to resolve the dispute without the need for further hearings, is primarily to seek a settlement by the parties. First, however, the chairman should determine the subject of the dispute and explain the positions of the parties, both as to the facts and as to the legal arguments of each party. When this stage is over, in accordance with Article $205^{6} \S 2$ of the Civil Procedure Code, the chairman should encourage the parties to reconcile and strive for amicable settlement of the dispute, in particular through mediation. ${ }^{15}$ The statement contained in the commentary on Article $205^{6}$ of the Civil Procedure Code under the editorship of A. Zieliński and K. Flaga-Gieruszyńska seems unjustified, that from the logical point of view the order of regulations in individual paragraphs should be such that at first the solutions

${ }^{13}$ Cf. judgement of the Supreme Court of 2 December 2000, V CKN 175/00, Legalis.

${ }^{14}$ K. Flaga-Gieruszyńska, A. Zieliński, Kodeks postępowania cywilnego. Komentarz, Legalis 2019, commentary on Article 232 of the Civil Procedure Code, note no. 3.

${ }^{15}$ More broadly, see Mediation in the Polish Legal Order, eds. A. Korybski, M. Myślinnska, P. Kłos, "Studia Iuridica Lublinensia" 2018, vol. 27(3). 
ought to be sought to reconcile the parties and achieve amicable settlement of the dispute, and only then to precisely outline the subject of the dispute and determine the positions of the parties together with their legal justification. ${ }^{16}$ To my mind, considerations about a settlement are factual when the positions of the parties are precisely clarified first. This gives both parties the opportunity to recognise the other party's reason as well as the strength of their own arguments, or lack thereof. A thorough understanding of the other party's position, also in terms of its legal justification, allows rational assessment of one's chances of winning the case. Since the parties got into dispute and a further stage of the proceedings took place, namely the setting of date of preparatory hearing, undoubtedly new circumstances should occur which may result in settlement and sometimes even withdrawal of lawsuit. These new circumstances are clarification of the positions of both parties, learning the legal justification for this position, which may not have been clearly presented in the parties' letters (lawsuit, defence, or further preparatory letters).

Therefore, M. Krakowiak rightly notes that the preparatory session consists of three stages. The first stage is informative (explanatory), during which the chairman determines the subject of the dispute with the parties, explains the parties' positions as to the facts and legal grounds of the dispute (Article $205^{6} \S 1$ of the Civil Procedure Code). The second stage is conciliatory and consists in persuading the parties to reconcile and amicably resolve the dispute (Article $205^{6} \S 2$ of the Civil Procedure Code). The third stage of the preparatory hearing is post-conciliatory and its purpose is to prepare a plan for the hearing. It takes place when no amicable settlement of the case is achieved. ${ }^{17}$

At this stage of the proceedings, the chairman's new entitlement will also be of significance under Article $156^{1}$ of the Civil Procedure Code, namely a provision that gives the chairman the right to inform a party about the likely outcome of a case in the light of the claims and evidence submitted to date. ${ }^{18}$

It should be emphasized that forwarding of such instruction is not a basis for any of the parties to successfully lead to appearance of new evidence in proceedings, with the argument that the need to invoke them arose later. The need to add evidence later does not mean that the party only completes the conclusions of evidence only thanks to the instructions of the chairman, the chairman does not give these instructions in order to help one of the parties win the trial, but in order to make the party or parties aware that their arguments and the command have certain shortcomings,

${ }^{16}$ K. Flaga-Gieruszyńska, A. Zieliński, op. cit., commentary on Article $205^{6}$ of the Civil Procedure Code, note no. 1.

${ }_{17}$ M. Krakowiak, Nowelizacja Kodeksu postępowania cywilnego moca ustawy z dnia 4 lipca 2019 r. (część II - Organizacja postępowania; Rozprawa), "Monitor Prawniczy” 2019, no. 20, pp. 1091-1092.

${ }_{18}$ Cf. J. Jankowski, Nowelizacja Kodeksu postepowania cywilnego moca ustawy z 4.7.2019 r., "Monitor Prawniczy" 2019, no. 18, p. 983. 
which may ultimately result in a certain outcome of the case, likely at this stage of the proceedings. This instruction is primarily intended to be an impulse for the parties to consider the possibility of reaching a settlement.

A. Michałowski and P. Milart indicate that the instruction of the chairman about the probable outcome of the case only exceptionally and in unprecedented cases will be the reason for the need to add new evidence at a later stage of the trial (after approval of the trial plan). ${ }^{19}$

Therefore, if the chairman decides to use his new entitlement, the content of the notice may significantly affect the chances of reaching a settlement. Of course, much will depend on how this instruction will be provided and what content it will have. If the argument of only one of the parties in the proceedings results clearly from the instruction, then most likely it will not result in a settlement, because the party whose arguments will be shared by the chairman will not be interested in concessions, and the settlement should be based on reciprocal concessions.

The problem is obviously not unequivocal, because the provisions do not show that the court is bound by instruction on the likely outcome of the case. It should be noted, however, that in vast majority of civil cases the court is composed of one person, i.e. the chairman who gives the instruction referred to in Article $156^{1}$ of the Civil Procedure Code will later be a member of the court adjudicating in the case. Also in cases recognized in the broader (bench) composition, the practice is and probably will be such that, despite the formal equality of voting power of individual members of the adjudication panel, the position of a professional judge will be the most important.

If the chairman refrains from clearly indicating the probable outcome of the case and indicates the circumstances that may affect the content of the judgement and what effects may be associated with the course of the evidentiary proceedings, then this instrument may prove effective at an early stage of the proceedings in making the parties aware of their procedural situation in the chairman's assessment and what risk is associated with continuing the dispute.

The chairman's right introduced in the content of Article $156^{1}$ of the Civil Procedure Code evokes emotions and different opinions. ${ }^{20}$ Proponents of this regulation share the arguments contained in the justification for the bill, arguing that this solution leads to improved communication between the court and the parties, and indicates that the chairman got acquainted with the case and analysed the arguments presented in the letters.

19 A. Michałowski, P. Milart, Pouczenie przewodniczacego o prawdopodobnym wyniku sprawy - pożegnanie z sędzia Sfinksem, "Palestra" 2019, no. 11-12, p. 235.

${ }_{20}$ M. Antosiewicz, Sẹdzia będzie mógt poinformować o prawdopodobnym wyniku sprawy przed wyrokiem, 2019, www.rp.pl/W-sadzie-i-urzedzie/305309927-Sedzia-bedzie-mogl-poinformowac-o-prawdopodobnym-wyniku-sprawy-przed-wyrokiem.html [access: 18.01.2020]. 
Opponents point out that the new content of Article $156^{1}$ of the Civil Procedure Code violates the principle of judicial fairness, as well as the principle that the significance of evidence should not be assessed before it is produced (so-called prohibition of anticipation of evidence).

Undoubtedly, however, the new regulation, if skilfully applied, may contribute to the settlement of a larger number of cases at the initial stage of the proceedings.

Even before the entry into force of Article $156^{1}$ of the Civil Procedure Code, the court, quite frequently, especially at the first hearing, pointed out the legitimacy of considering amicable settlement of the dispute (the legal basis for this is Article $223 \S 1$ of the Civil Procedure Code), indicating to both parties that the outcome of proceedings may be different from their perceptions on this subject, the duration of proceedings may be significant, considerable costs may also arise during the proceedings especially those related to the opinions of court experts. It was also rightly pointed out that proceedings often do not end at the stage of issuing judgement by the court of first instance, but continue at the stage of appeal proceedings, which, due to significant burden on the court of second instance, often involves quite a long time of waiting for appeal hearing. The parties were also aware that appeal procedure is inseparably connected with further increase in the costs of the procedure.

All these arguments will probably also be raised in the current model of civil procedure, and in addition the chairman will be entitled to present his view as to the likely outcome of the case. It seems sensible to show the parties not only the strengths and weaknesses of their trial position, but also skilfully turning attention to how the results of taking individual evidence, reported by the parties, can potentially affect the final result of the case. Then, the parties with best knowledge of the facts will be able to reasonably assess the rationale for further judicial proceedings.

As a result of the preparatory hearing, the parties may be referred for mediation, and in some cases even the withdrawal of an action. As Ż. Rogozińska rightly points out, "the justification of the proposed changes put more emphasis on the mediation than the organizational nature of the conciliation hearing. The judge is not supposed to be associated only with the settlement of the dispute, but with its relief or even closing. The judge assumes the role of conciliator, trying to find and show the parties the solution to the conflict, and in some way suggesting the envisaged solution". ${ }^{21}$

The preparatory hearing may be adjourned only if one of the conditions occurred as specified in Article $205^{7} \S \S 1$ to 3 of the Civil Procedure Code, which is clearly indicated in the regulation contained in $\S 4$ of this Article. The adjournment may be related to referring the matter to mediation or result from other circumstances, such as for the purpose of conducting settlement negotiations outside mediation,

\footnotetext{
${ }^{21}$ Ż. Rogozińska, Posiedzenie przygotowawcze w postępowaniu cywilnym, Legalis 2019.
} 
it may also occur due to, e.g., the need to clarify the circumstances relevant to the further conduct and positions of the parties, including the actual possibility of an amicable conclusion of the case, e.g. the defendant wants to determine whether they will be able to obtain financing on certain dates to meet the proposed arrangements as to the payment dates of the liability.

An adjournment of a preparatory hearing may also result from one party's excused non-appearance. The adjournment may also take place at the joint request of the parties. A consistent request of the parties to adjourn a preparatory hearing is the only situation where the adjournment may occur for the second time, it results directly from the content of Article $205^{7} \S 3$ of the Civil Procedure Code.

In the content of Article $205^{7} \S 1$ of the Civil Procedure Code, the duty of the chairman to postpone the preparatory hearing is indicated if the parties are referred to mediation. It should be pointed out after P. Feliga that "this is a single reason for the obligatory adjournment of the preparatory hearing by the chairman ex officio and that this circumstance is a consequence of the parties' consent to mediation during the preparatory hearing in connection with the activities carried out by the chairman pursuant to Article $205^{6} \S 2$ of the Civil Procedure Code". ${ }^{22}$

It seems that Article $205^{7}$ of the Civil Procedure Code is a special provision in relation to Articles 214 and 215 of the Civil Procedure Code, as evidenced by both the content of the provision and the systematics of the Act.

It is rightly pointed out by $\mathrm{K}$. Flaga-Gieruszyńska that "it is very important to balance the proportion between the desire to achieve the objectives of the preparatory hearing and to cause excessive length of proceedings. For this reason, judges will have to attentively analyse actual intentions of the parties and the realistic prospects of ending the dispute at an early stage". ${ }^{23}$

\section{Hearing plan}

If the case is not reached amicably, it is necessary to fulfil the second purpose of the preparatory hearing, namely, to draw up a hearing plan. In accordance with Article $205^{9} \S 1$ of the Civil Procedure Code, the hearing plan must contain decisions as to the parties' evidence applications, replacing evidentiary ruling in this respect.

This is a completely new situation, hitherto unknown in the Civil Procedure Code, when motions as to evidence are decided not by the court in the form of a decision, but by the chairman by virtue of a de facto order. ${ }^{24}$ The explanatory

${ }^{22}$ Kodeks postępowania cywilnego. Komentarz, vol. 1: Artykuły 1-505 $5^{39}$, ed. T. Szanciło, Legalis 2019, commentary on Article 2057 of the Civil Procedure Code, note no. 2.

${ }^{23}$ K. Flaga-Gieruszyńska, A. Zieliński, op. cit., commentary on Article $205^{7}$ of the Civil Procedure Code, note no. 2.

${ }^{24}$ M. Krakowiak, op. cit., pp. 1084-1097. 
memorandum to the bill states that "this plan is a sui generis document, which is not a court ruling (draft Article $205^{10} \S 4$ ), although to some extent replacing it (draft Article $205^{9} \S 1$ )" ${ }^{25}$ Therefore, the legislator does not explicitly specify legal nature of the hearing plan. From Article $205^{10} \S 4$ sentence 2 of the Civil Procedure Code only those provisions of ordinance shall apply accordingly to the hearing plan. Undoubtedly, it is prepared by the chairman with the participation of the parties, and is also approved by the chairman. K. Knoppek rightly points out that since the provisions on the ordinance apply accordingly to the plan of the hearing, therefore the plan of the hearing should be approved by the chairman by signing it, as each order is. ${ }^{26}$

One should also agree with M. Dziurda that if the positions of the parties regarding the taking of a specific evidence are divergent - one of the parties demands that it be carried out and the other is omitting it - then the chairman must, in essence, settle the dispute. In such a situation, the evidence decision in the plan of the hearing (although it is signed by the parties) is in fact the decision of the presiding judge. ${ }^{27}$

The hearing plan is an official document (Article $244 \S 1$ of the Civil Procedure Code). ${ }^{28}$

It should be remembered that the chairman's decision unfavourable to the party may result in the need to submit a reservation pursuant to Article 162 of the Civil Procedure Code, and if a party is represented by a lawyer, legal advisor, patent attorney or Office of the Prosecutor General of the Republic of Poland (Prokuratoria Generalna Rzeczypospolitej Polskiej), the lack of objection deprives her of the right to rely on this failure in the further course of the proceedings, and thus primarily in any appeal proceedings. It results from Article $162 \S 2$ of the Civil Procedure Code, and exceptions to this rule are formulated in $\S 3$ of this Article (when the violation of the provisions of the procedure the court should take into consideration ex officio or when a party proves that it did not raise any objection without its fault).

A reservation ought to be made either at a preparatory hearing or at the next date of preparatory hearing (if it has been adjourned) or at the next hearing. It follows from the content of Article $162 \S 1$ sentence 2 of the Civil Procedure Code.

It should be noted that the content of Article 162 of the Civil Procedure Code also changed as a result of the discussed amendment. Previously, a party that was present at a hearing during which there was a failure to comply with the rules of

25 Justification of the draft act amending the Act - Civil Procedure Code and certain other acts, Print no. 3137, p. 17.

${ }^{26}$ K. Knoppek, Dowody i postepowanie dowodowe w sprawach cywilnych po nowelizacji. Kodeksu postępowania cywilnego z 4.07.2019 r., "Palestra" 2019, no. 11-12, p. 68.

${ }^{27}$ Kodeks postepowania cywilnego, ed. P. Rylski, Legalis, commentary to Article $205^{9}$ of the Civil Procedure Code, note no. 14.

${ }^{28}$ Kodeks postępowania cywilnego, vol. 1A: Komentarz. Art. 1-424 $4^{12}$, ed. A. Góra-Błaszczykowska, Legalis 2020, commentary on Article 244 of the Civil Procedure Code, notes no. 1-5. 
procedure could not raise objections at the next hearing, unlike a party that was not present at the hearing. ${ }^{29}$

In addition to the obligatory element of the hearing plan, which is the decision concerning the evidence applications of the parties, this document, as follows from the contents of Article $205^{9} \S 2$ of the Civil Procedure Code, if necessary, may also contain other arrangements or decisions referred to in this provision. These include, among others, setting dates for hearing and other activities in the case. As stated in Article $205^{10} \S 5$ sentence 2 of the Civil Procedure Code, delivering a hearing plan to a party is replaced by them being notified of the dates of hearing and other activities covered by the plan. The plan of the hearing ex officio is served on the parties, it can also take place immediately after the preparation of the plan at the preparatory hearing - the so-called personal service. ${ }^{30}$

Disputes as to individual issues covered by the hearing plan shall be settled by the chairman. When the hearing plan is prepared, it is signed by the parties and the chairman. In addition, it should be noted that the chairman approves the hearing plan, which is then an attachment to the minutes of the preparatory hearing.

The obligation to draw up a report on the preparatory hearing results from Article $205^{8}$ of the Civil Procedure Code. The scope of what is to be included in this report is largely dependent on the chairman, especially if it facilitates the settlement of a dispute without a hearing. According to the mentioned provision, what has happened during the preparatory hearing and concerns attempts to resolve the dispute amicably is not entered in the minutes or recorded. In Article $205^{8} \S 1$ of the Civil Procedure Code, the appropriate application of Article $183^{4} \S 3$ of the Civil Procedure Code was pointed out, which describes, as ineffective, invoking in the course of proceedings before a court or arbitral tribunal to settlement submissions, proposals for mutual concessions or other statements made in mediation proceedings. ${ }^{31}$ Therefore, invoking settlement arguments, proposals for concessions and the content of statements made during the preparatory hearing as arguments in its favour, deem ineffective in the course of further examination of the case, if, clearly, there is no settlement or withdrawal of the claim.

Changing the hearing plan is possible, regulations in this respect are included in Article $205^{11}$ of the Civil Procedure Code. Changing the hearing plan should be an exception and may occur as a result of a reaction to a change in the situation,

29 See P. Szczepanowski, Instytucja zastrzė̇é do protokołu-art. 162 KPC-praktyczne aspekty, “Monitor Prawniczy” 2016, no. 10, p. 554.

${ }^{30}$ M. Uliasz, Posiedzenie przygotowawcze i plan rozprawy, "Monitor Prawniczy” 2019, no. 21, p. 1143.

${ }^{31}$ Cf. M. Miszkin-Wojciechowska, Prawne gwarancje poufności mediacji gospodarczej i cywilnej-ocena regulacji prawa polskiego na tle wybranych rozwiazań w prawie obcym, "ADR Arbitraż i Mediacja" 2010, no. 2, p. 23; ruling of the Higher Disciplinary Court of 27 February 2016, WSD 58/15. 
in which case it is permissible to modify the set hearing plan, or prepare a new plan. ${ }^{32}$ Changing the hearing plan in a situation where it has become obsolete is made by court order. E. Marszałkowska-Krześ points out that a change in the plan of the hearing takes place by way of an order that may be issued both at the hearing and in closed session (cf. Article 148 of the Civil Procedure Code). The decision may be appealed against (cf. Article $394 \S 1$ and Article 3941a $\S 1$ of the Civil Procedure Code). ${ }^{33}$

A. Góra-Błaszczykowska points out that the hearing plan becomes obsolete when there is no need or possibility to implement any of the elements of the approved trial plan. ${ }^{34}$

On the other hand, S. Jaworski points out that the reasons causing the trial plan to become obsolete may be different, e.g. subject or objective transformations of claims, the need to change the dates and schedule due to random accidents. ${ }^{35}$

In a comment edited by J. Gołaczyński and D. Szostek, it was indicated that in the course of the examination of the case, a number of circumstances may arise which will make it impossible or seriously difficult to strictly follow the plan and carry out all activities within the planned time limits. Such circumstances may include, for example, the absence of a witness or a party being excused, or an extension of the deadline for drawing up an opinion by an expert. In such a situation, the plan for the hearing becomes obsolete and there is a need to change it. ${ }^{36}$

Before making changes to the hearing plan, the court is obliged to hear the parties after informing them about the scope of the change it plans to make. The regulations do not indicate in what form the hearing should take place, so it is possible either oral (after summoning the parties to the hearing) or in writing (obliging the parties to respond in writing to the change planned by the court, of which the parties will also be notified in writing by the court). The idea that the hearing plan is created jointly by the parties and the chairman is the provision of Article $205^{11} \S 2$ of the Civil Procedure Code, which provides that in the event when at least one of the parties objects to the change intended by the court, another preparatory hearing shall be held. The exception to the aforementioned rule is the situation, when the

${ }^{32}$ M. Kłos, [in:] Kodeks postepowania cywilnego, vol. 2: Komentarz do art. 205 $5^{1}-424^{12}$, ed. A. Marciniak, Legalis, commentary on Article $205^{11}$ of the Civil Procedure Code, note no. 2.

${ }^{33}$ E. Marszałkowska-Krześ, Kodeks postępowania cywilnego. Komentarz, Legalis 2019, commentary on Article $205^{11}$ of the Civil Procedure Code, note no. 3.3.

${ }^{34}$ Kodeks postepowania cywilnego, vol. 1A: Komentarz. Art. 1-42412, ed. A. Góra-Błaszczykowska, Legalis 2020, commentary on Article $205^{11}$ of the Civil Procedure Code, note no. 2.

35 S. Jaworski, Kodeks postepowania cywilnego. Komentarz do zmian, Legalis 2019, commentary on Article $205^{11}$ of the Civil Procedure Code, note no.1.

${ }^{36}$ Kodeks postepowania cywilnego. Komentarz do ustawy z 4.7.2019 r. o zmianie ustawy - Kodeks postępowania cywilnego oraz niektórych innych ustaw, eds. J. Gołaczyński, D. Szostek, Legalis 2019, commentary on Article $205^{11}$ of the Civil Procedure Code, note no. 1. 
change of the hearing plan involves only setting additional dates for questioning witnesses, experts or parties covered by the plan.

When the preparatory hearing is held once again, the approval of the hearing plan is made by the chairman in accordance with the regulations described above, and thus not by court by way of court decision, as in the change of the hearing plan.

According to Article $205^{11} \S 3$ of the Civil Procedure Code, if a need arises, a new hearing plan may be drawn up. The term "significant need" is vague; therefore, a significant situation is whether the extent of the necessary changes is so significant and extensive that it becomes justified to draw up a new hearing plan instead of modifying the existing one. The preparation of a new hearing plan must, due to the content of the provision, precede the next preparatory hearing.

The situations described above regarding changes to the hearing plan or preparation of a new hearing plan do not open the deadline for submitting new assertions and evidence.

The practice of applying the provision in question must account for the fact that the role of the hearing plan is to ensure the smooth conduct of the proceedings.

\section{DISCUSSION AND CONCLUSIONS}

The conducted research confirms the main hypothesis that the adopted shape of regulations concerning preparatory proceedings may contribute to increasing the efficiency of civil proceedings. At the same time, this institution is rarely used in practice.

Amendments to the civil procedure, which were made with force of the Act of 4 July 2019 on the amendment of the Act - Civil Procedure Code and certain other acts are very extensive. This can even be described as the introduction of a new model for this procedure. Among other things, the provisions introducing the preparatory hearing reflect these profound changes.

The new regulations are aimed at accelerating the proceedings by creating mechanisms encouraging the parties to settle the dispute amicably and forcing the parties to present all statements and evidence at the initial stage of the proceedings. The later activity of the parties in this regard will usually be met with the omission of statements and evidence as being delayed. Thanks to this, the procedure has a real chance of being completed faster. The new regulations introduce significant and practical restrictions on the possibility of deliberately dragging the case.

As always, only the practice of applying these provisions will actually determine the final shape of the changes introduced by the legislator. Only after some time will it be possible to fully assess the validity of the new regulations.

At present, it must be noticed that the preparatory hearings are very rarely scheduled, although this is not an institution criticized by practitioners. The reason for 
this may be the lack of precise knowledge of the introduced regulations or simply the lack of experience in drawing up the plan of the hearing. Concerns regarding the appointment of preparatory hearings may also result from the fact that in the course of the trial there may be situations where the prepared plan for the hearing will be partially outdated, which makes it necessary to proceed in accordance with Article $205^{11}$ of the Civil Procedure Code. These are additional steps that must be taken by the court or the chairman. Situations such as the absence of a witness or a prolonged time for the preparation of an expert opinion are commonplace in the realities of the Polish civil trial.

More frequent scheduling of preparatory hearings would probably contribute to accelerating cases, but the fear that an improperly prepared plan of the hearing may also cause procedural problems at later stages of the process may be the reason why the scheduling of preparatory sessions is not frequent.

A comprehensive training program for judges, with a strong emphasis on the workshop part, would also contribute to the popularization of this institution.

\section{REFERENCES}

\section{Literature}

Białecki M., [in:] Kodeks postępowania cywilnego. Komentarz do zmian 2019. Koszty sadowe w sprawach cywilnych. Dochodzenie roszczeń w postępowaniu grupowym. Przepisy przejściowe, ed. T. Zembrzuski, vol. 1, Legalis 2019.

Bodio J., Przygotowanie sprawy do rozpoznania - pisma i postępowanie przygotowawcze, [in:] Nowelizacja Kodeksu postępowania cywilnego z 4.7.2019 r. w praktyce, eds. K. Flaga-Gieruszyńska, R. Flejszar, M. Malczyk, Warszawa 2020.

Flaga-Gieruszyńska K., Zieliński A., Kodeks postępowania cywilnego. Komentarz, Legalis 2019.

Guzik T., Economic Justification of Judicial Discretion, "Studia Iuridica Lublinensia" 2020, vol. 29(3), DOI: http://dx.doi.org/10.17951/sil.2020.29.3.87-97.

Jankowski J., Nowelizacja Kodeksu postępowania cywilnego moca ustawy z 4.7.2019 r., "Monitor Prawniczy" 2019, no. 18.

Jasiuk E., Konstytucyjne prawo do sądu a pozycja prawno-procesowa przedsiębiorcy w odrębnym postępowaniu w sprawach gospodarczych oraz $w$ świetle ostatnich zmian $w$ Kodeksie postępowania cywilnego, "Rocznik WSH w Radomiu" 2006, vol. 3(1).

Jaworski S., Kodeks postępowania cywilnego. Komentarz do zmian, Legalis 2019.

Kłos M., [in:] Kodeks postepowania cywilnego, vol. 2: Komentarz do art. 205 $1424^{12}$, ed. A. Marciniak, Legalis.

Knoppek K., Dowody i postepowanie dowodowe w sprawach cywilnych po nowelizacji. Kodeksu postępowania cywilnego z 4.07.2019 r., "Palestra" 2019, no. 11-12.

Kodeks postępowania cywilnego, ed. P. Rylski, Legalis.

Kodeks postępowania cywilnego, vol. 1A: Komentarz. Art. 1-424 $4^{12}$, ed. A. Góra-Błaszczykowska, Legalis 2020.

Kodeks postępowania cywilnego. Komentarz do ustawy z 4.7.2019 r. o zmianie ustawy-Kodeks postępowania cywilnego oraz niektórych innych ustaw, eds. J. Gołaczyński, D. Szostek, Legalis 2019. 
Kodeks postępowania cywilnego. Komentarz, vol. 1: Artykuty 1-505 $5^{39}$, ed. T. Szanciło, Legalis 2019. Krakowiak M., Nowelizacja Kodeksu postępowania cywilnego moca ustawy z dnia 4 lipca 2019 r. (część II - Organizacja postępowania; Rozprawa), "Monitor Prawniczy” 2019, no. 20.

Marszałkowska-Krześ E., Kodeks postępowania cywilnego. Komentarz, Legalis 2019.

Mediation in the Polish Legal Order, eds. A. Korybski, M. Myślińska, P. Kłos, "Studia Iuridica Lublinensia" 2018, vol. 27(3).

Michałowski A., Milart P., Pouczenie przewodniczacego o prawdopodobnym wyniku sprawy - pożegnanie z sędzia Sfinksem, "Palestra" 2019, no. 11-12.

Miszkin-Wojciechowska M., Prawne gwarancje poufności mediacji gospodarczej i cywilnej-ocena regulacji prawa polskiego na tle wybranych rozwiazań w prawie obcym, "ADR Arbitraż i Mediacja” 2010, no. 2.

Rogozińska Ż., Posiedzenie przygotowawcze w postępowaniu cywilnym, Legalis 2019.

Szczepanowski P., Instytucja zastrzeżeń do protokolu - art. 162 KPC-praktyczne aspekty, "Monitor Prawniczy” 2016, no. 10.

Tomaszek A., Nowe powinności adwokackie po nowelizacji procedury cywilnej, "Palestra" 2019, no. $11-12$.

Uliasz M., Posiedzenie przygotowawcze i plan rozprawy, "Monitor Prawniczy” 2019, no. 21.

\section{Online sources}

Antosiewicz M., Sędzia będzie mógł poinformować o prawdopodobnym wyniku sprawy przed wyrokiem, 2019, www.rp.pl/W-sadzie-i-urzedzie/305309927-Sedzia-bedzie-mogl-poinformowac-o-prawdopodobnym-wyniku-sprawy-przed-wyrokiem.html [access: 18.01.2020].

Justification of the draft act amending the Act - Civil Procedure Code and certain other acts, Print no. 3137, https://orka.sejm.gov.pl/Druki8ka.nsf/0/166CCC44490F3965C1258384003CD40A/\%24File/3137-uzas.pdf [access: 10.11.2021].

\section{Legal acts}

Act 4 July 2019 amending the Act - Code of Civil Procedure and certain other acts (Journal of Laws 2019, item 1469).

\section{Case law}

Judgement of the Supreme Court of 2 December 2000, V CKN 175/00, Legalis.

Ruling of the Higher Disciplinary Court of 27 February 2016, WSD 58/15. 
Pobrane z czasopisma Studia Iuridica Lublinensia http://studiaiuridica.umes.pl Data: 26/04/2023 17:11:45

Preparatory Hearing in the Light of the Amendment to the Civil Procedure Code...

\begin{abstract}
ABSTRAKT
Niniejszy artykuł jest opracowaniem o charakterze naukowo-badawczym, w którym zawarta jest analiza nowych regulacji prawnych dotyczących posiedzenia przygotowawczego $\mathrm{w}$ postępowaniu cywilnym w świetle nowelizacji Kodeksu postępowania cywilnego z dnia 4 lipca 2019 r. Celem jest omówienie instytucji posiedzenia przygotowawczego oraz próba odpowiedzi na pytania, czy przyjęty kształt regulacji może przyczynić się do zwiększenia sprawności postępowań cywilnych oraz dlaczego instytucja ta jest dość rzadko stosowania w praktyce. Oprócz regulacji prawnych dotyczących instytucji posiedzenia przygotowawczego przedstawiono także rozważania dotyczące znaczenia praktycznego poszczególnych regulacji i ich wpływu na przebieg postępowania cywilnego oraz to, z jakich powodów przepisy te są nadal dość rzadko stosowane w praktyce. Artykuł dotyczy tematyki o zasięgu krajowym, szczególnie istotnej dla praktyków prawa.
\end{abstract}

Słowa kluczowe: postępowanie cywilne; posiedzenie przygotowawcze; sprawność postępowań cywilnych; Kodeks postępowania cywilnego; nowelizacja 